\title{
NIH urged to cap profits made on publicly funded research
}

\& Colin Macilwain, Washington

The US National Institutes of Health (NIH) is caught in the crossfire over one of the most contentious issues in the US presidential campaign: the high cost of therapeutic drugs.

In particular, the medical agency is under political pressure to cap or recover profits on drugs whose development was based on publicly funded research. But this is being opposed by the pharmaceutical and biotechnology industry, and also by US universities and medical colleges, which benefit substantially from the current arrangement.

Last week, intensive lobbying by the pharmaceutical industry helped to defeat two amendments to the NIH's Senate funding bill. These would have forced radical changes in the rules for the transfer of technology resulting from publicly funded research from universities to corporations.

One amendment, proposed by Senator Ron Wyden (Democrat, Oregon) but later withdrawn, would have required universities to repay grants to the NIH if research led to a commercial product. And drug companies would have had to pay a $1 \%$ levy to the NIH on drugs with annual sales of $\$ 500$ million.

Under the current system, implemented largely through the landmark 1980 BayhDole Act, companies often pay licensing fees to the institution that patented an innovation. But neither the companies nor the institution have to pay the government anything.

The Bayh-Dole Act was intended to allow corporations freedom to patent and profit from publicly supported university research without entering into complex legal agreements with the government. The act is credited by some economists as key to the success of the US biotechnology industry, which has grown much faster than its counterparts abroad.

But the high prices charged by the drug industry for drugs partially developed with public funds do not sit well with Congress.

"The thing that is providing the heat on this issue is the intense political jockeying over prescription drug benefits," says David Korn, vice-president for research at the Association of American Medical Colleges.

Last week, an amendment from Wyden was added to the Labor, Education, Health and Human Services appropriations bill. It requires the NIH director to report to the Senate "a proposal to require a reasonable rate of return on both intramural and extramural research by March 31st, 2001”. But this addition came after Wyden had withdrawn his initial wording.

Another amendment, from Senator Paul Wellstone (Democrat, Minnesota), would have prohibited licensing deals unless the

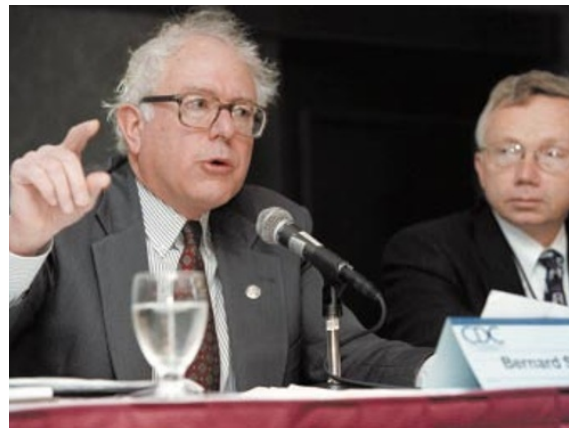

Sanders: claims Americans are currently paying twice for life-saving drugs.

drug companies involved reached "reasonable pricing" agreements with the government. It was rejected by the Senate last Friday.

The sentiments behind this amendment are already supported in the House of Representatives. Last month, the House approved an amendment to its NIH funding bill, proposed by Bernie Sanders (Independent, Vermont), to reimpose "reasonable pricing".

John Porter (Republican, Illinois), chair of the House Labor, Education Health and Human Services appropriations subcommittee, says the amendment will have little effect. Although it prohibits NIH funding for licensing agreements, these are normally funded directly by universities.

But the amendment's easy passage indicates the strength of feeling on the issue. Many in Congress find it hard to argue with Sanders' line that "Americans must pay twice for lifesaving drugs, first as taxpayers to develop the drug and then as consumers to pad pharmaceutical profits". In a newspaper interview last week, Al Gore, the Democratic nominee in this year's presidential election, said that he supported the Sanders amendment.

Porter, who opposed the amendment, says the NIH already demands a return when it collaborates with industry on research directed at a particular disease. But he says the argument now is about demanding returns from basic research, whose contribution to drug development is hard to measure.

The NIH sought to impose "reasonable pricing" of drugs when Bernadine Healy was its director, but her successor Harold Varmus abandoned the idea in 1995.

But a spokesman for the Association of American Universities says it is "concerned about opening up the Bayh-Dole Act through the appropriations process, without thorough hearings and careful deliberations".

The failure of the Wellstone amendment lifts that threat for now. But Bayh-Dole still looks vulnerable, says Korn. "In a presidential election year, anything could happen.”

\section{Indian space agency sets its sights on a mission to the Moon}

\section{K. S. Jayaraman, Bangalore}

The Indian Space Research Organisation (ISRO) is to submit a feasibility report to the government seeking permission and funding for a scientific mission to the Moon. The ISRO says it can launch the mission by 2005 if it gets the go-ahead.

The report, due to be delivered in about three months, is being prepared by an ISRO team assembled to look into the feasibility, cost and benefits of the project.

S. Rangarajan, mission coordinator and ISRO director for satellite communications, says the mission will cost about US\$90 million - roughly a fifth of the ISRO's budget for 1999. He says it will be "a one-shot affair, not a continuing moon programme".

The ISRO is considering modifying India's Polar Satellite Launch Vehicle to send a lunar orbiter carrying sensors and high-resolution cameras. "The orbiter will be a lighter version of the remotesensing satellites we have been building for over a decade," says P. S. Goel, director of the ISRO Satellite Centre.

According to Rangarajan, the mission has already been endorsed by India's scientific community. And ISRO chairman Krishnaswami Kasturirangan says the mission would "provide an impetus to science in India" and serve as a test-bed for future space missions.

But not all scientists are so keen. H. S. Mukunda, chairman of the aerospace engineering department at the Indian Institute of Science in Bangalore, says the country is unlikely to benefit from repeating what others did 30 years ago.

The ISRO has listed several possible scientific objectives, including detailed mapping, studying the distribution of rare elements, and analysing the surface composition. It has also invited proposals from the research community.

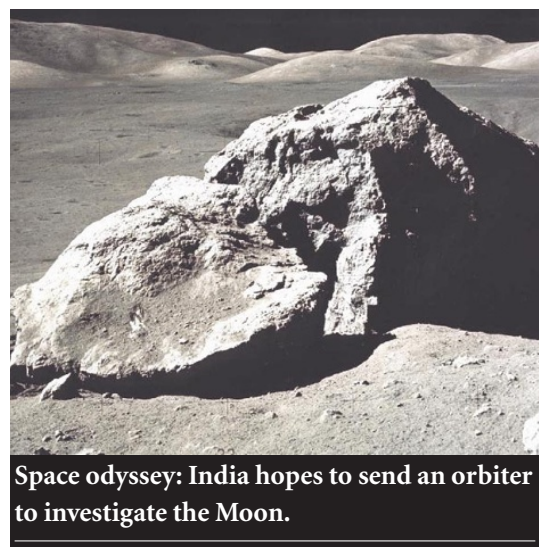

